\title{
Stock Market Investment and Inflation: Evidence from the United States and Canada.
}

\author{
JANESH SAMI \\ School of Accounting, Finance and Economics \\ The University of the South Pacific \\ Suva, Fiji Islands. *
}

\begin{abstract}
This paper examines the long-run relationship between goods prices and stock prices to understand whether stock market investment can help hedge against inflation in the United States (US) and Canada. This study employed an autoregressive distributed lag (ARDL) cointegration test developed by Pesaran, Shin, and Smith (2001), and finds evidence of a positive long-run economic relationship between stock prices and goods prices in both economies over the sample period 1960 to 2019. The long-run elasticity is above one for both economies implying that the developments in the goods market significantly affect the stock market. We undertake a suite of sensitivity checks and find robust evidence that the stock market investment can help hedge against inflation in the United States and Canada.
\end{abstract}

Keywords: Stock prices, Goods prices, Cointegration, Inflation, Stock Market Investment JEL Classifications: C22; C32; E31; G10; G11; G15

\section{Introduction}

Whether stocks can provide a hedge against inflation has long been a subject of debate since the 1970s (see, for instance, Bodie, 1976). The Generalized Fisher hypothesis (Fisher 1930) as applied to common stocks suggests that stock market investment should provide a hedge against inflation ${ }^{1}$ (Gregoriou \& Kontonikas, 2010; Luintel \& Paudyal, 2006; Omay, Hasanov, Yuksel, \& Yuksel, 2016; Omay , Yuksel, \& Yuksel, 2015). In past, several studies have examined whether stocks can indeed provide a hedge against inflation by examining the relationship between stock return and inflation (Al-Khazali \& Pyun, 2004; Alagidede \& Panagiotidis 2012;

\footnotetext{
*Email: samij@@usp.ac.fj; Phone: (+679) 3232534; ORCID: 0000-0002-1020-5435. An earlier version of this paper was presented at the 9th RMUTP International Conference on Science, Technology and Innovation for Sustainable Development, Bangkok, Thailand (21-22 June 2018). I am grateful for the comments made by Lei Pan (Monash University, Australia) and Professor Paresh Narayan (Deakin University, Australia). I also thank the anonymous reviewers of this journal for their comments and suggestions that significantly help improve this paper. All errors are my own.

(C) 2021 Janesh Sami . Licensed under the Creative Commons Attribution - Noncommercial 4.0 Licence (http://creativecommons.org/licenses/by-nc/4.0/. Available at http: //rofea.org.
} 
Gultekin, 1983; Khil \& Lee, 2000; Kim \& In, 2005; Rushdi , Kim, \& Silvapulle, 2012; Spyrou, 2001, 2004).

There are two emerging strands of empirical literature on stock prices and goods prices. The first strand of empirical literature comprises single-country studies or multi-country studies. For instance, Al-Nassar and Bhatti (2018) used monthly data for emerging market economies covering the sample period 1982:01 to 2016:01 to investigate the long-run relationship between stock prices and goods prices. The Johansen cointegration and ARDL bounds cointegration tests results revealed mixed evidence of cointegration between stock prices and goods prices across countries. They found that stocks help hedge against inflation over the long-run in over one-third of the cases. Alagidede and Panagiotidis (2010) examined the relationship between stock prices and goods prices in six African Countries (South Africa, Nigeria, Kenya, Egypt, Morocco, and Tunisia) using monthly data for different sample periods but also found mixed support for Generalized Fisher Hypothesis (GFH). Hassan, Hoque, and Rao (2015) investigated the relationship between stock prices and goods prices in 19 OECD countries using monthly data using linear and nonlinear cointegration tests, and also found mixed results to support GFH. However, Kim and Ryoo (2011) studied the long-run economic relationship between stock prices and goods prices in the US using monthly data from 1900:01 to 2009:06 within a non-linear cointegration framework, and documented strong evidence that common stocks have been a hedge against inflation from 1950 .

Luintel and Paudyal (2006) examined whether common stocks help hedge against inflation in the United Kingdom using monthly industry-level data from 1955:01 to 2002:12. The results supported existence of positive cointegrating relationship between pairs of stock indexes and retail price index. Anari and Kolari (2001) investigated the relationship between stock prices and goods prices in six industrial countries (the US, Canada, the UK, France, Germany, Japan) using monthly data from 1953:01 to 1998:12. The estimates of long-run coefficient of goods prices ranged from 1.04 to 1.65 across the six economies and supported the Fisher hypothesis. Ely and Robinson (1997) studied the relationship between stock prices and goods prices in 16 industrialized countries using quarterly data from 1957:01 to 1992:3 and documented evidence that stocks help hedge against inflation in most countries.

The second strand comprises panel studies, which found firm support for the cointegrating relationship between stock prices and goods prices. Omay et al. (2016) documented strong evidence of cointegrating relationship between stock prices and goods prices in a sample of 52 countries (21 developed, 19 emerging and 12 others) covering the sample period January 1997:01 to 2008:12 by employing residual-based cointegration test that accounts for both, cross-sectional dependence and structural breaks. Omay, Yuksel, and Yuksel (2015) examined the relationship between stock prices and goods prices in a sample of 52 countries using monthly data from 1997:1 to 2008:12. The study emphasized on accounting for cross-sectional dependence and employed panel unit root test, cointegration test and panel estimators that 
allowed for cross-sectional dependence, and found evidence to support GFH. Gregoriou and Kontonikas (2010) studied the long-run relationship between stock prices and goods prices in 16 OECD countries using annual data from 1970 to 2006 within a panel unit root and cointegration framework. The empirical results showed a positive long-run relationship between goods prices and stock prices, suggesting that common stocks provide a hedge against inflation. Hence, overall, a review of both strands of the literature shows that empirical evidence remains inconclusive.

Three issues pertaining to the extant literature motivate the present study. First, previous studies have found mixed evidence on whether stocks can provide a hedge against inflation. It is still unclear whether stock market investment is useful for investors to hedge against inflation. A notable limitation of bulk of past studies is that they have not accounted for other macroeconomic factors (for example, economic activity, exchange rate, interest rates and money supply) that affect stock prices and its relationship with good prices. Second, past studies use stock return and inflation to examine whether stocks can provide a hedge against inflation. This approach throws away long-run information (Anari \& Kolari, 2001; Gregoriou \& Kontonikas, 2010; Madadpour \& Asgari, 2019), and therefore does not help understand whether stock market investment can provide a hedge against inflation. In contrast, an empirical analysis of the relationship between stock prices and goods prices allows full use of the longrun information (Gregoriou \& Kontonikas, 2010; Omay et al., 2015) and therefore, is relatively more insightful. Third, recent panel studies have their own limitations. In particular, it is difficult for investors to make investment decisions relating to different stock markets based on panel results. The main goal of this paper is to investigate the economic relationship between stock prices and goods prices in the United States and Canada within a time series cointegration framework.

This paper contributes to the literature in three ways. First, we focus on stock markets in two important economies in the world that have a long history of trade and financial linkages, with Canada being the second largest trading partner of the United States. Many Canadian firms are cross-listed on the US exchanges and often raise funds in the US capital markets (Hussain and Omrane 2020). Second, we undertake an empirical analysis of the cointegrating relationship between stock prices and goods prices covering six decades (1960 to 2019)-a relatively large sample period compared to past studies. It is worthwhile to note, in contrast to past panel studies that have collected data for several countries for a shorter period of time, we undertake country-specific analysis covering a larger sample period to examine cointegration between stock prices and good prices. This approach is useful for two important reasons. First, it allows us to undertake a comparative examination of the cointegrating relationship between good and stock prices in Canada (a small open economy) and the United States (a relatively closed economy). This insight is useful for investors in choosing between two stock markets for investment to hedge against inflation. Second, this approach also allows us to see if there is 
a breakdown in the cointegrating relationship between goods and stock prices over the sample period.

The third contribution of this paper is that we undertake a suite of robustness checks to examine the sensitivity of our empirical results. In addition, unlike most of past studies, we control for other factors (for example, money supply, long-term interest, exchange rate, industrial production), and possible structural breaks in the relationship between goods prices and stock prices due to: 1973 Oil Embargo, 1987 stock market crash, 2008 Global Financial Crisis and Great Recession. This helps us show our findings are robust to alternative model specification, structural breaks, choice of sample period, and variable measurement.

Foreshadowing our major results, this study documents a positive, significant and stable long-run relationship between the stock prices and goods prices in both economies over six decades. We undertake a suite of sensitivity checks and find robust evidence for the US and Canada. There is strong evidence that stock market investment can help hedge against inflation in the US and Canada.

The organization of the paper is as follows. Section 2 discusses the data sources and empirical methodology, while Section 3 discusses the empirical results. Section 4 reports and discusses results from sensitivity analysis. Section 5 provides the concluding remarks and policy implications.

\section{Data and Empirical Methodology}

\subsection{Data and Empirical Model}

To study whether stocks can provide a hedge against inflation, we examine the long-run relationship between the stock prices and goods prices. Following Kim and Ryoo (2011), Gregoriou and Kontonikas (2010), Luintel and Paudyal (2006), and Anari and Kolari (2001), the long-run relationship between stock prices $\left(\operatorname{In} S P_{t}\right)$ and goods prices $\left(I n G P_{t}\right)$ is expressed as follows ${ }^{2}$ :

$$
\operatorname{In} S P_{t}=\alpha+\beta \operatorname{In} G P_{t}+\varepsilon_{t}
$$

We are primarily interested in the size and significance of slope coefficient, $\beta$. It is the elasticity of stock prices with respect to the goods prices and called the Fisher coefficient. If the estimated coefficient takes a value of one, this would imply that the in the long-run, common stocks are a hedge against inflation (Gregoriou \& Kontonikas, 2010; Kim \& Ryoo, 2011; Luintel \& Paudyal, 2006). However, since income from stocks is subject to taxes, the long-run rate of return must exceed the inflation rate, at least by the tax rate (Luintel \& Paudyal, 2006). Thus, in order for common stocks to be a hedge against inflation in the long-run, the estimated value of the Fisher coefficient must exceed one. 
The sample period for both economies is 1960 to 2019 . We collected annual data on stock prices and goods prices for the US and Canada. We extracted data for the stock prices and goods prices (consumer price index) from OECD iLibrary website (OECD, 2021). Consistent with standard econometric practice; we converted both series to natural logarithms, so that we can interpret the estimated coefficient as elasticity. All estimations were done in Microfit 5.0, Eviews and Gauss packages.

\subsection{Empirical Methodology}

The empirical analysis starts by examining the order of integration of the stock prices and goods prices for both countries. This study, therefore initially employs two widely used univariate time series unit root test, namely the augmented Dickey-Fuller test (ADF) (Dickey \& Fuller, 1979, 1981) and Phillips-Perron (PP) unit root test (Phillips \& Perron, 1988) to determine the order of integration of the variables. Given that both unit root tests are widely discussed in the applied economics literature, we do not discuss here details to conserve space.

It is important to note, however, ADF and PP unit root tests do not account for structural breaks and lead us to incorrectly conclude the order of integration of variables-which might later affect our choice of cointegration test and estimators. Perron (1989) suggests that unit root tests that do not allow for structural break will suffer from low power to reject the null of hypothesis of a unit root. Hence, this study resorts to unit root tests that account for break(s) in the series developed by Zivot and Andrews (1992) and Narayan and Popp (2010).

\section{Zivot-Andrews (1992) Unit Root Test}

We employ version $\mathrm{C}$ of Zivot-Andrews unit root test by estimating equation (2). In a seminal paper, Sen (2003) has demonstrated that Model C version of the Zivot-Andrews unit root test that allows for a change in both slope and intercept minimizes the loss of power, and is relatively superior to Model A (allows for a change in the intercept) and Model B (allows for a change in the slope). The null hypothesis in the present context, therefore, is that stock prices and goods prices, individually, are an integrated process without a structural break. The alternative hypothesis is that both series are trend stationary with a structural break in the trend function that occurs at an unknown time.

$$
\Delta \operatorname{In} y_{t}=\alpha_{0}+\emptyset \operatorname{In} y_{t-1}+\beta T+\delta_{1} D U_{t}+\varphi_{1} D T_{t}+\sum_{j=1}^{k} \tau_{j} \Delta \operatorname{In} y_{t-j}+v_{t}
$$

In equation (2), In $y_{t}$ denotes series under consideration - $\log$ of the stock prices $\left(\operatorname{In} S P_{t}\right)$ and the goods prices $\left(\operatorname{In} G P_{t}\right) . T$ denotes time trend. $\Delta$ is the first difference operator, $v_{t} \sim i i d\left(0, \sigma^{2}\right), t=1 \ldots . n$. Estimating equation (1) provides us with estimates of various 
parameters $\left(\varnothing, \beta, \delta_{1}, \varphi_{1}, \tau\right)$. We also include an additional term in equation (2), to account for serial correlation and ensure that error term is well-behaved; $\Delta \operatorname{In} y_{t-j}$. We, however, are mainly interested in the coefficient of $\phi$.

The break date in two series are determined by selecting the value of the break date (TB) for which the ADF $t$-statistic for $\phi$ is maximized. The other variables in equation (2) are defined as follows: $D U_{t}$ is an indicator dummy variable representing a mean shift occurring at time $T B$, $D T_{t}$ is the trending shift variable, where $D U_{t}=1$ and $D T_{t}=t-T B$ if $t>T B$; otherwise 0 .

\section{Narayan and Popp (2010) Unit Root Test}

We also consider the possibility of multiple structural breaks in stock prices and good prices by applying unit root test developed by Narayan and Popp (2010). Narayan and Popp (2013) investigated small sample size and power properties of unit root tests that allows for multiple structural breaks developed by Lee and Strazicich (2003), Lumsdaine and Papell (1997) and Narayan and Popp (2010), and find that Narayan and Popp (2010) unit root test has a better size, high power and identifies structural break dates more correctly. The Narayan and Popp (2010) unit root test is implemented by estimating the two models (equation 3 and 4).

\section{Model 1}

$$
\begin{aligned}
& y_{t}=\rho y_{t-1}+\alpha_{1}+\beta * t+\phi_{1} D\left(T^{\prime}{ }_{B}\right)_{1, t}+\phi_{2} D\left(T^{\prime}{ }_{B}\right)_{2, t} \\
& +\theta_{1} D U^{\prime}{ }_{1, t-1}+\theta_{2} D U_{2, t-1}^{\prime}+\sum_{j=1}^{k} \beta_{j} \Delta y_{t-j}+\varepsilon_{1 t}
\end{aligned}
$$

\section{Model 2}

$$
\begin{gathered}
y_{t}=\rho y_{t-1}+\alpha_{2}+\beta * t+\delta_{1} D\left(T_{B}^{\prime}\right)_{1, t}+\delta_{2} D\left(T_{B}^{\prime}\right)_{2, t} \\
+\theta_{1} D U^{\prime}{ }_{1, t-1}+\theta_{2} D U^{\prime}{ }_{2, t-1}+\varphi_{1} D{T^{\prime}}_{1, t-1}+\varphi_{2} D T_{2, t-1}^{\prime}+\sum_{j=1}^{\beta_{j}} \beta_{j} \Delta y_{t-j}+\varepsilon_{2 t}
\end{gathered}
$$

Model 1 allows for two structural breaks in the level, while Model 2 allows for two structural breaks in the level and the slope. The unit root hypothesis of $\rho=1$ is tested against the alternative hypothesis of $\rho<1$. The $t$-statistic of $\hat{\rho}$ is denoted as $t_{\widehat{\rho}}$. $T_{B, i}^{\prime}, i=1,2$ denotes break dates, $D U_{i, t}^{\prime}=1\left(t>T_{B, i}^{\prime}\right), D T_{i, t}^{\prime}=1\left(t>T_{B, i}^{\prime}\right)\left(t-T_{B, i}^{\prime}\right)$. The structural break dates can be determined using grid search and sequential procedure. However, the break dates are not much different and sequential procedure is less computationally demanding (Narayan and Popp 2010). 


\section{Cointegration Test}

Before estimating the empirical model as specified in equation (1), we examine if the stock prices and goods prices are cointegrated. Engle and Granger (1987) have shown that, if two series are integrated of order one, and have a common stochastic trend, then the two series have a long-run relationship. Finding evidence of a cointegrating or long-run relationship between stock prices and goods prices is important as it rules out the possibility of a spurious relationship.

We employ an autoregressive distributed lag (ARDL) cointegration test developed by Pesaran, Shin, and Smith (2001). ARDL cointegration test enables us to examine the cointegrating relationship between variables that are integrated of different order and is an improvement over traditional cointegration tests such as Johansen and Engle-Granger cointegration tests (which requires all variables to be I(1)). In addition, use of ARDL technique allows for estimation in presence of endogenous variables and very useful in small samples (Haug, 2002; Pesaran \& Shin, 1999; Pesaran et al., 2001). The ARDL representation of the relation is expressed as:

$\Delta \operatorname{In} S P_{t}=\alpha_{1}+\sum_{i=1}^{\rho} \gamma_{k} \Delta \operatorname{In} S P_{t-k}+\sum_{i=1}^{\rho} \delta_{k} \Delta \operatorname{In} G P_{t-k}+\pi_{1} \operatorname{In} S P_{t-1}+\pi_{2} \operatorname{In} G P_{t-1}+v_{t}$

$\Delta \operatorname{In} G P_{t}=\alpha_{2}+\sum_{i=1}^{\rho} \gamma_{k} \Delta \operatorname{In} S P_{t-k}+\sum_{i=1}^{\rho} \delta_{k} \Delta \operatorname{In} G P_{t-k}+\pi_{1} \operatorname{In} S P_{t-1}+\pi_{2} \operatorname{In} G P_{t-1}+v_{t}$

In equation (5-6), $\Delta$ is the first difference operator and $v_{t}$ is the disturbance term. All variables are defined as before. The ARDL cointegration test is conducted using OLS and conducting a joint significance test for the hypothesis that there is no cointegrating relationship between stock prices and goods prices. This involves testing the null hypothesis, $H_{0}: \pi_{1}=\pi_{2}=0$ (no cointegrating relationship between stock prices and goods prices) against the alternative hypothesis of $H_{1}: \pi_{1} \neq \pi_{2} \neq 0$ (cointegrating relationship between stock prices and goods prices).

We compare the resulting $F$-statistics with the critical $F$-value provided by Narayan (2005). If the computed $F$-statistic exceeds the $F$-critical value from Narayan (2005), then we reject the null hypothesis of no cointegrating relationship between stock prices and goods prices in favour of the alternative hypothesis that stock prices and goods prices are cointegrated. This would imply that stock prices and goods prices share a meaningful long-run economic relationship.

\section{Estimation of the long-run relationship}

If stock prices and goods prices are cointegrated, then the Fisher coefficient can be estimated using following equation: 
Review of Economic Analysis 13 (2021) 339-365

$$
\text { In } S P_{t}=\beta_{0}+\sum_{i=1}^{m} \alpha_{1} \operatorname{In} S P_{t-i}+\sum_{i=1}^{n} \varphi_{1} \operatorname{In} G P_{t-i}+u_{t}
$$

In order to estimate the short-run coefficients and the speed of adjustment, we estimate equation (8) below. The speed of adjustment is captured by the parameter $\lambda$ and measures how fast the disequilibrium in stock prices is restored, following shocks to goods prices. We expect the sign of the adjustment parameter to be negative, and its statistical significance can be interpreted as further evidence of cointegration between stock prices and goods prices.

$$
\Delta \operatorname{In} S P_{t}=\alpha_{0}+\sum_{i=1}^{k} \alpha_{1 i} \Delta \operatorname{In} S P_{t-i}+\sum_{i=0}^{k} \alpha_{2 i} \Delta \operatorname{In} G P_{t-i}+\lambda E C M_{t-1}+v_{t}
$$

\section{Empirical Results}

\subsection{Unit Root Test Results}

We first examine the unit root properties of stock and good prices using the ADF and PP unit root tests. The results are not reported here to conserve space but are available from authors upon request. The results consistently show that stock prices in Canada and United States are non-stationary, I (1). The unit root hypothesis is not rejected in the levels of the stock price series. However, the unit root hypothesis is rejected at 1 percent level for stock prices in the first difference in both countries. Interestingly, we find that the unit root hypothesis is not rejected in levels and first difference for good prices in Canada. The inability to reject the null hypothesis of a unit root could be because ADF and PP unit root tests do not account for structural breaks. This study, therefore, considers structural breaks by employing ZivotAndrews (1992) unit root test that accounts for a single structural break. We summarize the results in Table 1 below. Colum 2 reports the test-statistics, column 3 presents the estimated break date for the series and column 4 shows the optimal lag length $(k)$ selected with AIC criteria. We cannot reject the null hypothesis of a unit root in the stock prices with a structural break in both the intercept and trend when unit root test is conducted in levels.

The results indicate stock prices are non-stationary series in Canada and the United States. The computed test-statistics is -4.409 and is less than critical value at $5 \%$ significance level. However, the null hypothesis is rejected at $1 \%$ significance level when stock prices in Canada are expressed in the first difference. For the US, the computed test-statistics is -3.827 and is less than critical value at $5 \%$ significance level, when stock prices are considered in levels. However, the null hypothesis of a unit root with a structural break in both the intercept and trend is rejected at $1 \%$ significance level when stock prices are expressed in the first difference. The estimated break date of 2001 is possibly related to September $11^{\text {th }}$ Terrorist Attack. Thus, the results indicate that that stock prices in the US and Canada are I(1) variables. In contrast, good prices are I (1) variable in Canada and I(0) variable in the US. 
SAMI Stock Market Investment and Inflation

Table 1: Zivot-Andrews (1992 Unit Root Test Results

\begin{tabular}{|l||c|c|c|c|}
\hline Variable & t-statistic & Break date & $\mathrm{k}$ & Conclusion \\
\hline \hline $\begin{array}{l}\text { In } S P_{t} \\
(\text { Canada) }\end{array}$ & -4.409 & 1979 & 0 & \\
$\begin{array}{l}\Delta \text { In } S P_{t} \\
\text { (Canada) }\end{array}$ & $-6.547 * * *$ & 1978 & 4 & $\mathrm{I}(1)$ \\
$\begin{array}{l}\text { In } G P_{t} \\
(\text { Canada) }\end{array}$ & -4.441 & 1978 & 1 & \\
$\begin{array}{l}\Delta \text { In } G P_{t} \\
(\text { Canada) }\end{array}$ & $-5.971 * * *$ & 1983 & 1 & $\mathrm{I}(1)$ \\
$\begin{array}{l}\text { In } S P_{t} \\
(\mathrm{US})\end{array}$ & -3.827 & 1996 & 8 & $\mathrm{I}(1)$ \\
$\begin{array}{l}\Delta I n S P_{t} \\
(\mathrm{US})\end{array}$ & $-7.080 * * *$ & 2001 & 1 & $\mathrm{I}(0)$ \\
$\begin{array}{l}\text { In } G P_{t} \\
(\mathrm{US})\end{array}$ & $-5.775 * * *$ & 1979 & 3 & \\
$\begin{array}{l}\Delta \text { In } G P_{t} \\
(\mathrm{US})\end{array}$ & $-6.254 * * *$ & 1983 & 2 & \\
\hline
\end{tabular}

Notes: $* * *$ denotes statistical significance at $1 \%$. The maximum lag length is set to 8 . The critical value at $1 \%$ is -5.57 and at $5 \%$ is -5.08 .

Table 2 presents the Narayan and Popp (2010) unit root test results that allow for multiple structural breaks. We report the test-statistics and two estimated break dates for both cases: Model 1 and Model 2. The unit root hypothesis is not rejected for stock prices for both countries. The computed test-statistics are insignificant in levels. However, the unit root hypothesis is easily rejected for stock prices in the first difference form at 1 percent and 5 percent level, for Canada and the United States, respectively. The results are robust to selection of model. Thus based on the results in Table 2, stock prices are found to be I(1).

For the good prices, the NP results are less clear. The results for good prices for Canada appear to be mixed and dependent upon choice of model. Model 1 results indicate good prices are I(1) while Model 2 results implies that unit root hypothesis can be rejected in levels at 1 percent level. In case of the United States, good prices are found to be I(1). The computed teststatistic under Model 1 is -5.903 and exceeds critical value -5.529 at 1 percent level, goods prices is $\mathrm{I}(1)$ variable.

The unit root hypothesis is not rejected under Model 2. Thus, we consider Model 1 results for good prices for the United States, and examine the long-run relationship between stock prices and goods prices. This also suggests it is appropriate to use an autoregressive distributed lag modeling approach to test cointegration between stock prices and goods prices in the United States and Canada. 
Review of Economic Analysis 13 (2021) 339-365

Table 2: Narayan and Popp (2010) Unit Root Test Results

\begin{tabular}{|c|c|c|c|c|c|c|}
\hline Variable & \multicolumn{3}{|c|}{ Model 1} & \multicolumn{3}{|c|}{ Model 2} \\
\hline & t-statistic & TB1 & TB2 & t-statistic & TB1 & TB2 \\
\hline $\begin{array}{l}\text { In } S P_{t} \\
\text { (Canada) }\end{array}$ & -1.877 & 1982 & 1999 & -2.522 & 1982 & 1999 \\
\hline $\begin{array}{l}\Delta I n S P_{t} \\
\text { (Canada) }\end{array}$ & $-7.588 * * *$ & 1982 & 1999 & $-7.227 * * *$ & 1982 & 1999 \\
\hline $\begin{array}{l}\text { In } G P_{t} \\
\text { (Canada) }\end{array}$ & 1.731 & 1982 & 1991 & $-6.124 * * *$ & 1980 & 1991 \\
\hline $\begin{array}{l}\Delta I n G P_{t} \\
\text { (Canada) }\end{array}$ & $-5.429 * *$ & 1982 & 1991 & $-5.323 * *$ & 1982 & 1991 \\
\hline $\begin{array}{l}\operatorname{In} S P_{t} \\
(\mathrm{US})\end{array}$ & -1.108 & 1973 & 1982 & -3.735 & 1975 & 2001 \\
\hline $\begin{array}{l}\Delta \operatorname{In} S P_{t} \\
(\mathrm{US})\end{array}$ & $-4.876^{* *}$ & 1982 & 1984 & $-5.844 * *$ & 1982 & 2001 \\
\hline $\begin{array}{l}\operatorname{In} G P_{t} \\
\text { (US) }\end{array}$ & 1.552 & 1973 & 1982 & -2.798 & 1982 & 1986 \\
\hline $\begin{array}{l}\Delta \operatorname{In} G P_{t} \\
(\mathrm{US})\end{array}$ & $-5.903 * * *$ & 1976 & 1984 & -4.049 & 1974 & 1982 \\
\hline
\end{tabular}

Notes: The critical values are taken for Narayan and Popp (2010). For Model 1, the critical values are: $1 \%(-5.529) ; 5 \%(-4.514) ; 10 \%(-4.143)$. For Model 2 , the critical values are: $1 \%(-5.949) ; 5 \%(-5.181) ; 10 \%(-4.789) . * * *$ denotes statistical significance at 1 percent level and $* *$ denotes statistical significance at 5 percent level.

\subsection{Cointegration Results}

Table 3 presents the ARDL cointegration test results for the United States and Canada. To ensure that our results are not sensitive to inclusion of trend, we report the cointegration test results for both cases: with constant only; with both constant and trend.

\section{Cointegration Results for the United States:}

In the first case, when only constant is included; we find evidence of a cointegrating relationship. When stock prices is considered the dependent variable, the computed F-statistic is 6.085 and exceeds the critical $F$-value at 5\% significance level. Hence, we can reject the null hypothesis of no long-run relationship between stock prices and goods prices. When the goods prices is considered the dependent variable, the null hypothesis of no long-run relationship between the variables cannot be rejected. As reported in Table 3, the computed F-statistic of 1.869 is below the reported critical $F$-value, thus we find no evidence of cointegration in this case. Therefore, we only find evidence of a long-run relationship between stock prices and goods prices in the United States when stock prices is the dependent variable. 
SAMI Stock Market Investment and Inflation

Table 3: ARDL Cointegration Results (1960-2019)

\begin{tabular}{|c|c|c|c|c|}
\hline \multirow[t]{2}{*}{$F$-test } & \multicolumn{4}{|c|}{ Computed $F$-Statistics } \\
\hline & \multicolumn{2}{|c|}{ With constant } & \multicolumn{2}{|c|}{ With constant and trend } \\
\hline $\begin{array}{l}F\left(\operatorname{In} S P_{t} \mid \operatorname{In} G P_{t}\right) \\
F\left(\operatorname{In} G P_{t} \mid \operatorname{In} S P_{t}\right) \\
\end{array}$ & $\begin{array}{c}\text { US } \\
6.085^{* *} \\
1.869\end{array}$ & $\begin{array}{c}\text { Canada } \\
3.045 \\
0.963 \\
\end{array}$ & $\begin{array}{c}\mathrm{US} \\
6.286^{* *} \\
3.065 \\
\end{array}$ & $\begin{array}{l}\text { Canada } \\
10.682^{* * *} \\
1.404 \\
\end{array}$ \\
\hline & \multicolumn{4}{|c|}{ F-critical value } \\
\hline $\begin{array}{l}1 \% \\
5 \% \\
10 \%\end{array}$ & $\begin{array}{c}\mathrm{I}(0) \\
7.400 \\
5.125 \\
4.145\end{array}$ & $\begin{array}{c}\mathrm{I}(1) \\
8.510 \\
6.000 \\
4.950\end{array}$ & $\begin{array}{c}\mathrm{I}(0) \\
6.780 \\
4.980 \\
4.230\end{array}$ & $\begin{array}{c}\mathrm{I}(1) \\
7.377 \\
5.527 \\
4.693\end{array}$ \\
\hline
\end{tabular}

Notes: Critical values are extracted from Narayan (2005). *** and ** denotes significance at $1 \%$ and $5 \%$, respectively.

In the second case, when both constant and time trend is included, we still find evidence of a long-run relationship in the United States. When stock price is considered the dependent variable, the computed $F$-statistic is 6.286 and exceeds the critical $F$-value of 5.547 at 5\% significance level. Hence, we can reject the null hypothesis of no long-run relationship between stock prices and goods prices. When the goods prices are considered the dependent variable, the null hypothesis of no long-run relationship between the variables cannot be rejected. As reported in Table 3, the computed $F$-statistic of 3.065 is below the reported critical F-value, thus we find no evidence of cointegration in this case. Therefore, we only find evidence of a long-run relationship between stock prices and goods prices in the United States when stock prices is considered the dependent variable. This finding is similar to our earlier result on cointegration test between stock prices and goods prices. Thus, in case of the US, the cointegration result is robust.

\section{Cointegration Results for Canada:}

There is no evidence of a long-run relationship between stock prices and goods prices when only constant is included in cointegration test equation. When stock prices is considered the dependent variable, the computed $F$-statistic is 3.045 and is below the critical $F$-value at $10 \%$ significance level. When the goods prices is considered the dependent variable, the null hypothesis of no long-run relationship between the variables cannot be rejected. As reported in Table 3, the computed $F$-statistic of 0.963 is below the reported $F$-critical value, thus we find no evidence of cointegration in this case. Thus, with only constant is included, there is no evidence of a long-run relationship between goods prices and stock prices in Canada. 
In the second case, when both constant and time trend is included, we find evidence of a long-run relationship in Canada. There is sound evidence of a long-run relationship between stock prices and goods price. When stock price is considered the dependent variable, the computed $F$-statistic is 10.682 and above the $F$-critical value at $1 \%$ significance level. Hence, we can reject the null hypothesis of no long-run relationship between stock prices and goods prices, in favour of the alternative that there is a long-run relationship between stock prices and goods prices. When the goods prices is considered the dependent variable, the null hypothesis of no long-run relationship between the variables cannot be rejected. As reported in Table 3, the computed $F$-statistic of 1.404 is below the reported $F$-critical value, thus we find no evidence of cointegration in this case. Thus, as constant and trend is included, there appears to be evidence of a long-run relationship between goods price and stock prices in Canada, when stock prices is considered the dependent variable.

To sum up, the cointegration test results reported in Table 3 shows that there is evidence of a long-run relationship between stock prices and goods prices in the United States and Canada. The cointegration test result appears to be quite robust in case of US. In case of Canada, there is evidence of cointegrating relationship between stock prices and goods prices, when time trend is included.

\subsection{Estimates of the long-run relationship}

Table 4 reports the estimated long-run and short-run estimates for the US and Canada. We present the result for the US in Panel A. The estimated long-run coefficient of goods prices is positive and estimated to be 1.54 . The estimated coefficient is statistically significant at 1 percent significance level. In the long-run, a one percent increase in the goods prices is associated with 1.54 percent increase in the stock prices in the US. This suggests that changes in the good prices have strong positive impact on stock prices over the long-run. The coefficient of the lagged $E C M_{t-1}$ is negative and statistically significant at 1 percent significant level. This confirms our F-test cointegration result that stock prices and goods prices have a long-run relationship in the US. The estimated model for US passes tests for serial correlation, model mis-specification and heteroscedasticity.

For Canada, the estimated long-run coefficient of goods price is positive and estimated to be 0.48 . The estimated coefficient is statistically significant at 5 percent significance level. In the long-run, a one percent increase in the goods prices is associated with 0.48 percent increase in the stock prices in Canada. This suggests that changes in the good prices have a positive impact on the stock prices over the long-run. The coefficient of the lagged $E C M_{t-1}$ is negative and statistically significant at 1 percent significance level. The estimated model passes tests for serial correlation, model mis-specification and heteroscedasticity. Thus, the estimated long-run coefficient of good prices in the United States is 1.54 , while the estimated long-run coefficient of goods prices in Canada is about 0.48 . 
SAMI Stock Market Investment and Inflation

Table 4: Estimation Results (1960-2019)

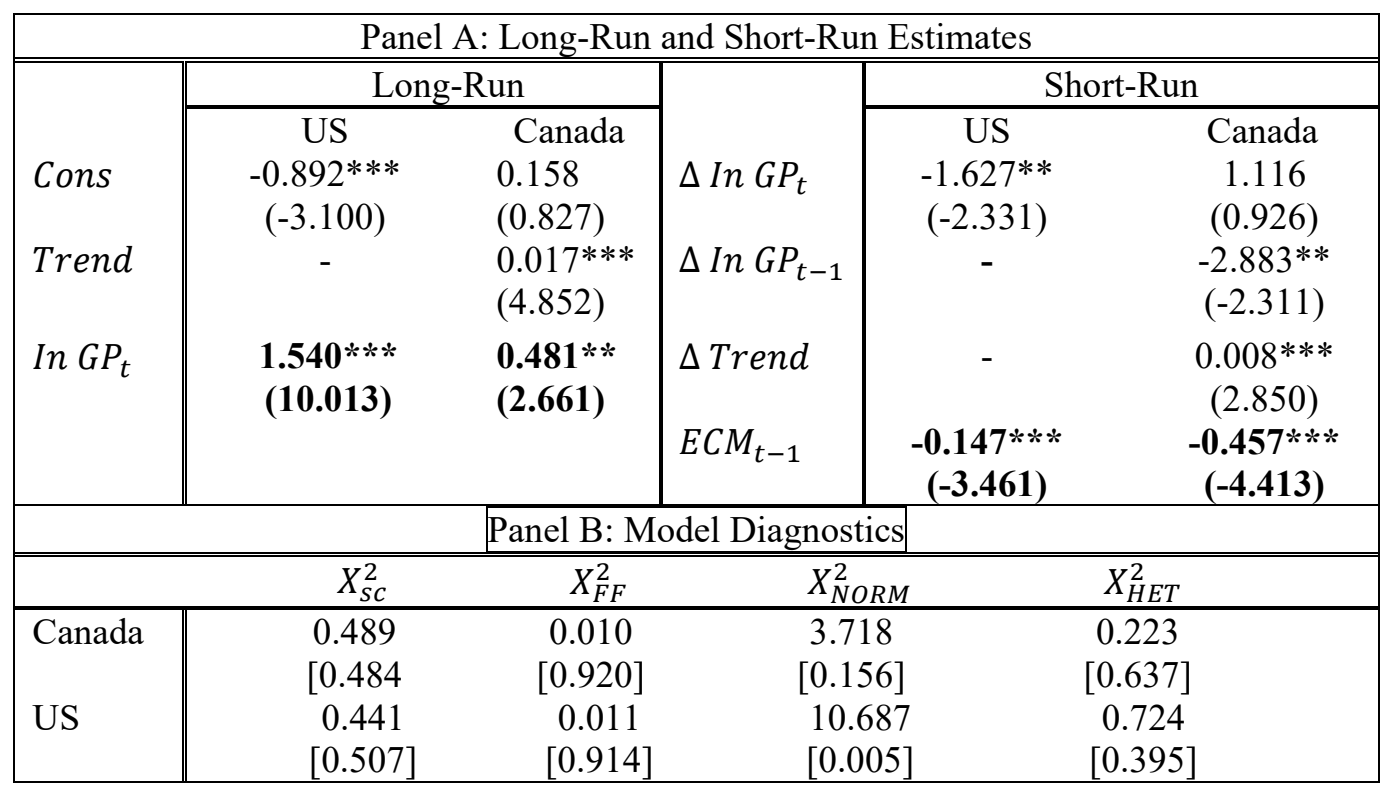

Notes: In Panel A, reported values are coefficients and figures in brackets are test-statistics. *** denotes statistical significance at $1 \%$ level. $* *$ indicates significance at $5 \%$ level. For Model diagnostics, figures in brackets are p-values. The dependent variable is logged stock price $\left(\right.$ In $\left.S P_{t}\right)$.

Our study reveals that stock prices respond to changes in the good prices in the United States. We find both the goods market and stock market are closely connected in the long-run. Overall, our estimated value of Fisher coefficient is 1.54 and is not very much different from Anari and Kolari (2001) who report estimates in the range 1.04 to 1.65 for six industrial countries. Our finding here differs from Hassan et al. (2015) who found no evidence of cointegration between stock prices and goods prices in the US.

In both countries, we observe a statistically significant positive relationship between stock prices and good prices. However, in terms of the size of the Fisher coefficient, goods market has a relatively stronger influence over stock market in the United States compared to Canada. We find that the R-Squared (Coefficient of Determination) for the United States is about 0.20, suggesting the model explains 20 percent of variation in the stock prices. For Canada, the Rsquared is about 0.30 implying good prices explains 30 percent of variation in the stock prices.

The differences in the results could be attributed to the nature of the two economies. The Canada is a small open economy, implying that its stock market is not only affected by domestic goods market but other major stock markets, energy markets, financial market openness and macroeconomic policy developments abroad (including the United States). For example, a recent study by Hussain and Omrane (2020) has found that US macroeconomic news 
announcements affect the Canadian stock market. Bhuiyan and Chowdhury (2020) points that stock markets in Canada respond differently to macroeconomic variables compared to the United States because of independence of monetary policy. Employing a structural VAR model, $\mathrm{Li}$, İşcan, \& Xu (2010) find that the immediate and dynamic responses of stock prices to a contractionary monetary policy differ in Canada and the United States ${ }^{3}$.

\section{Sensitivity Analysis}

In this section, we undertake and discuss the results from several sensitivity checks, to see if our estimates of Fisher coefficient for two countries are robust. This is important to ensure that the estimates of Fisher coefficient: a) are stable over the sample period 1960 to 2019; b) insensitive to use of a particular dataset; c) insensitive to use of alternative measurement of goods prices; d) insensitive to particular choice of sample period; and e) insensitive to inclusion of additional variables (alternative model specification) and important economic events such as 1973 OPEC embargo, 1987 stock market crash, and 2008 Great Recession that affected the stock market ${ }^{4}$.

\subsection{Use of Alternative Dataset on Stock Prices}

As the first sensitivity check, we re-estimated the long-run and short-run elasticities for the US and Canada using annual seasonally unadjusted share prices data for the same sample period (1960 to 2019) from an alternative data source - FRED Economic Data (Federal Reserve Bank of St. Louis, 2020).

We use share prices from an alternative source to check if our results are sensitive to choice of a particular dataset. The long-run and short-run elasticities are summarized in Table 5. The estimated Fisher coefficient for the US is 1.541 similar to the initial estimate of 1.540 as reported in Table 4. For Canada, the estimated Fisher coefficient is 0.485 similar to the initial estimate of 0.481 as reported in Table 4. If we compare the short-run estimates and adjustment parameter reported in Table 4 and Table 5, we note quantitatively similar results. Thus, the long-run and short-run estimates are robust for both economies, and unlikely to be sensitive to choice of a particular dataset.

\subsection{Use of Alternative Measures of Good Prices}

We now consider an alternative measure of goods prices - GDP deflator. We re-estimated the long-run and short-run elasticities using GDP deflator from World Development Indicators (World Bank 2021). If our baseline results are sensitive to a specific measure of goods prices (that is, Consumer Price Index), then the estimated coefficients should differ significantly. 
SAMI Stock Market Investment and Inflation

Table 5: Estimation Results (1960-2019)

\begin{tabular}{|c|c|c|c|c|c|}
\hline \multicolumn{6}{|c|}{ Panel A: Long-Run and Short-Run Estimates } \\
\hline & \multicolumn{2}{|c|}{ Long-Run } & & \multicolumn{2}{|c|}{ Short-Run } \\
\hline Cons & $\begin{array}{c}\text { US } \\
-0.893 * * * \\
(-3105)\end{array}$ & $\begin{array}{c}\text { Canada } \\
0.153 \\
(0.805)\end{array}$ & $\Delta \operatorname{In} G P_{t}$ & $\begin{array}{c}\text { US } \\
-1.630^{* *} \\
(-2326)\end{array}$ & $\begin{array}{c}\text { Canada } \\
1.259 \\
(1070)\end{array}$ \\
\hline Trend & - & $\begin{array}{c}0.017 * * * \\
(4.861)\end{array}$ & $\Delta \operatorname{In} G P_{t-1}$ & - & $\begin{array}{c}-3.032 * * \\
(-2.490)\end{array}$ \\
\hline \multirow[t]{2}{*}{ In $G P_{t}$} & $\begin{array}{l}1.541 * * * \\
(10.023)\end{array}$ & $\begin{array}{c}0.485 * * * \\
(2.704)\end{array}$ & $\Delta$ Trend & - & $\begin{array}{c}0.008 * * * \\
(2.861)\end{array}$ \\
\hline & & & $E C M_{t-1}$ & $\begin{array}{c}-0.147 * * * \\
(-3.460)\end{array}$ & $\begin{array}{c}-0.458 * * * \\
(-4.460)\end{array}$ \\
\hline \multicolumn{6}{|c|}{ Panel B: Model Diagnostics } \\
\hline & $X_{S C}^{2}$ & $\bar{C}_{F F}^{2}$ & $X_{N O R M}^{2}$ & $X_{H E T}^{2}$ & \\
\hline Canada & $\begin{array}{c}0.610 \\
{[0.435]}\end{array}$ & $\begin{array}{c}0.001 \\
{[0.974]}\end{array}$ & $\begin{array}{c}4.037 \\
{[0.133]}\end{array}$ & $\begin{array}{c}0.228 \\
{[0.633]}\end{array}$ & \\
\hline US & $\begin{array}{c}0.441 \\
{[0.506]}\end{array}$ & $\begin{array}{c}0.013 \\
{[0.909]}\end{array}$ & $\begin{array}{c}10.633 \\
{[0.005]}\end{array}$ & $\begin{array}{c}0.708 \\
{[0.400]}\end{array}$ & \\
\hline
\end{tabular}

Notes: In Panel A, reported values are coefficients and figures in brackets are test-statistics. *** denotes statistical significance at $1 \%$ level. $* *$ indicates significance at $5 \%$ level. For Model diagnostics, figures in brackets are p-values. The dependent variable is logged stock price $\left(\operatorname{In} S P_{t}\right)$. The computed $F$-statistics when stock price is considered the dependent variable are as follows: US (6.081); Canada (10.969). For US, we find evidence of cointegration at $5 \%$ significance level; For Canada, we find evidence of cointegration at $1 \%$ significance level. Plot of Cumulative Sum of Recursive Residuals and Plot of Cumulative Sum of Squares of Recursive Residuals indicates the estimated model is stable over the sample period in both countries. The results are available from the author upon request.

Table 6 - Panel A indicates that the estimated long-run coefficient of goods prices is 1.695 and 0.387 and not very different from the initial estimates of 1.541 and 0.485 for both countries. The estimated coefficient is statistically significant at 1 percent for the US and 5 percent for Canada. In both countries, the statistical significance of a coefficient of lagged $E C M_{t-1}$ confirms earlier evidence of the cointegrating relationship between stock prices and goods prices. Thus, based on the comparison of Table 4 and Table 6, we note our baseline results for the US and Canada are quite robust and not sensitive to alternative measure of good prices.

\subsection{Stability of Fisher Coefficient over 1960 to 2019}

In this sub-section section, we consider whether the estimated relationship between stock prices and good prices are stable in the US and Canada. We examine the stability of the relationship 
Review of Economic Analysis 13 (2021) 339-365

Table 6: Estimation Results (1960-2019) Using GDP Deflator

\begin{tabular}{|c|c|c|c|c|c|}
\hline \multicolumn{6}{|c|}{ Panel A: Long-Run and Short-Run Estimates } \\
\hline \multirow{7}{*}{$\begin{array}{l}\text { Cons } \\
\text { Trend } \\
\text { In } G P_{t}\end{array}$} & \multicolumn{2}{|c|}{ Long-Run } & & \multicolumn{2}{|c|}{ Short-Run } \\
\hline & US & Canada & & US & Canada \\
\hline & $-1.170 * * *$ & 0.269 & $\Delta \operatorname{In} G P_{t}$ & $-2.153 * * *$ & 1.052 \\
\hline & $(-3.080)$ & (1.368) & & $(-2.401)$ & (1.318) \\
\hline & - & $\begin{array}{c}0.018 \\
(5.164)\end{array}$ & $\Delta \operatorname{In} G P_{t-1}$ & 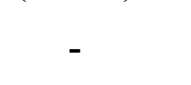 & $\begin{array}{l}-2.618 * * * \\
(-3.256)\end{array}$ \\
\hline & $1.695 * * *$ & $0.387 * *$ & $\Delta$ Trend & & $0.007 * * *$ \\
\hline & & & $E C M_{t-1}$ & $\begin{array}{l}-0.136 * * * \\
(-3.409)\end{array}$ & $\begin{array}{l}(2.743) \\
\mathbf{- 0 . 3 9 9 * * *} \\
(\mathbf{- 4 . 0 9 5 )}\end{array}$ \\
\hline \multicolumn{6}{|c|}{ Panel B: Model Diagnostics } \\
\hline & $X_{S C}^{2}$ & $X_{F F}^{2}$ & $X_{N O R M}^{2}$ & $\overline{X_{H E T}^{2}}$ & \\
\hline \multirow[t]{2}{*}{ Canada } & 0.649 & 0.061 & 3.654 & 0.059 & \\
\hline & [0.799] & {$[0.805]$} & [0.161] & [0.808] & \\
\hline \multirow[t]{2}{*}{ US } & 0.311 & 0.152 & 8.045 & \multirow{2}{*}{$\begin{array}{c}0.792 \\
{[0.373]}\end{array}$} & \\
\hline & [0.577] & [0.697] & {$[0.018]$} & & \\
\hline
\end{tabular}

Notes: In Panel A, reported values are coefficients and figures in brackets are test-statistics. *** denotes statistical significance at $1 \%$ level. $* *$ indicates significance at $5 \%$ level. For Model diagnostics, figures in brackets are p-values. The dependent variable is logged stock price $\left(\right.$ In $\left.S P_{t}\right)$. The computed $F$-statistics when stock price is considered the dependent variable are as follows: US (5.885); Canada (9.619). For US, we find evidence of cointegration at $10 \%$ significance level; For Canada, we find evidence of cointegration at $1 \%$ significance level. Plot of Cumulative Sum of Recursive Residuals and Plot of Cumulative Sum of Squares of Recursive Residuals indicates the estimated model is stable over the sample period in both countries. The results are available from the author upon request.

using CUSUM and CUSUMSQ tests developed by Brown, Durbin, and Evans (1975). The plot of Cumulative Sum of Recursive Residuals and plot of Cumulative Sum of Squares of Recursive Residuals are shown in Figure 1 and 2 suggest that the estimated relationship between stock prices and goods prices are stable over time in the US. For Canada, plot of Cumulative Sum of Recursive Residuals and plot of Cumulative Sum of Squares of Recursive Residuals are shown in Figure 3 and 4 suggest that the estimated relationship between stock prices and goods prices are stable over time.

The plots indicate that the long-run relationship between stock prices and goods prices has been stable over the sample period in both countries. We also examined the stability of the relationship using rolling OLS in Microfit and recursive OLS in Eviews. In both cases, the plots indicate evidence of the stable relationship between stock prices and goods prices in the US and Canada. We do not report the results of rolling OLS and recursive OLS here to conserve space, but they are available from the author upon request. 
SAMI Stock Market Investment and Inflation

Figure 1: Plot of Cumulative Sum of Recursive Residuals (US)

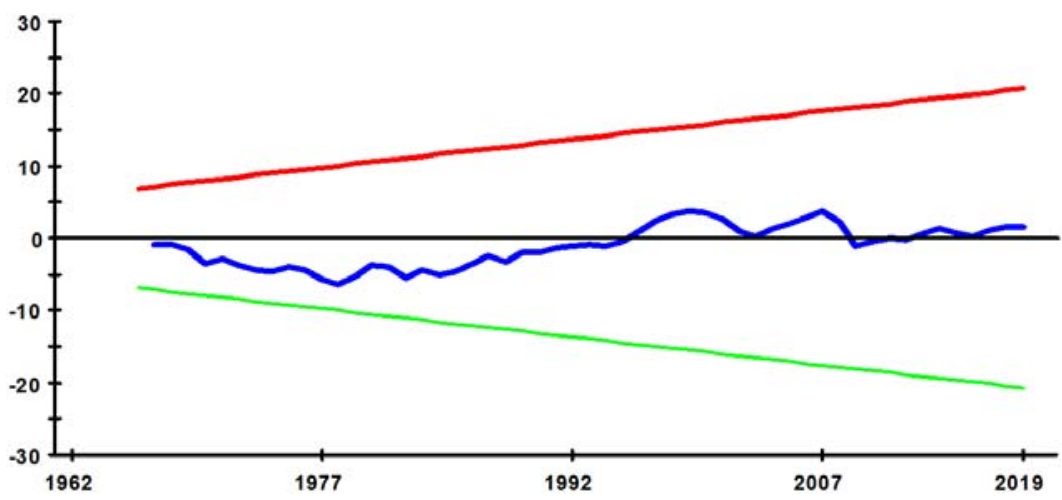

Figure 2: Plot of Cumulative Sum of Squares of Recursive Residuals (US)

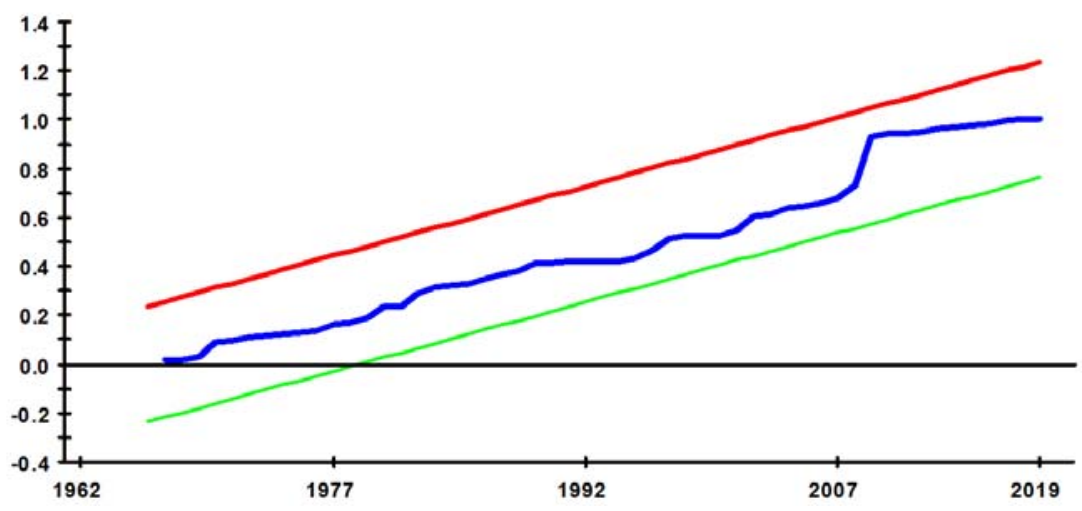

Figure 3: Plot of Cumulative Sum of Recursive Residuals (Canada)

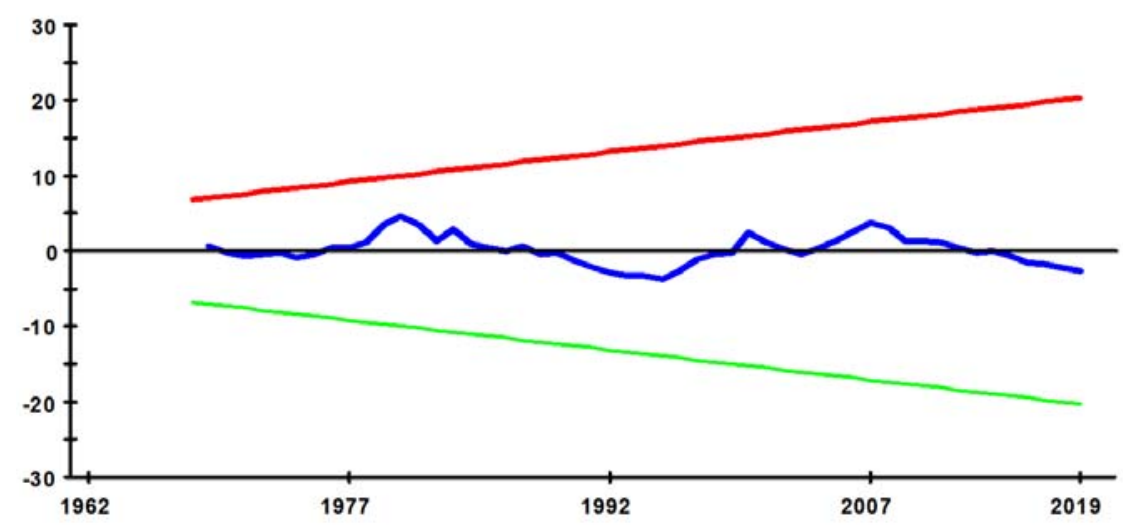


Figure 4: Plot of Cumulative Sum of Squares of Recursive Residuals (Canada)

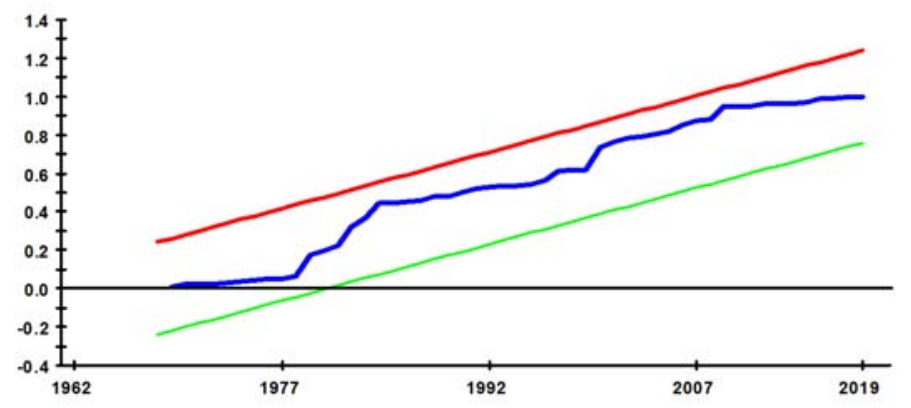

Note: the straight lines in figures 1-4 represent critical bounds at $5 \%$ significance level

\subsection{Use of Alternative Sample Period}

Finally, we re-estimated the empirical model for an alternative sample period, so we can examine if our estimates are sensitive to a specific choice of sample period. The results for the US appear to be robust, as we can note that the size of Fisher coefficient is around 2, only marginally different from 1.5. The speed of adjustment parameter to be statistically significant at $1 \%$ level, confirming cointegration between stock prices and goods prices (see Table 7). For Canada, the estimated size of Fisher coefficient is 0.53 and very close to the initial estimated value of 0.48 (see Table 4). The coefficient is statistically significant at $5 \%$ level. The speed of adjustment parameter for Canada is statistically significant at $1 \%$ level, supporting cointegration between stock prices and goods prices. Therefore, the results for Canada and the US are robust, and not sensitive to selection of sample period.

\subsection{Estimation of an Augmented Regression Model}

In this sub-section, we re-estimated the relationship between stock prices and good prices in the United States and Canada, including additional macroeconomic control variables and possible structural breaks to capture the effects of 1973 Oil Embargo, 1987 stock market crash, 2008 Global Financial Crisis and Great Recession ${ }^{5}$.

Macroeconomic variables affect stock prices by influencing the discount rate or future expected cash flows (Humpe and Macmillan 2009). In the discounted cash flow or present value model, stock prices are linked to expected future cash flows and the future discount rate. An increase in the economic activity (output) raises cash flows and positively affects stock prices (Ratanapako and Sharma 2007). We follow Ratanapako and Sharma (2007) and use industrial production, as it explains more variation in the stock return compared to other measures. Thus, we expect stock prices and industrial production to be positively related. 
SAMI Stock Market Investment and Inflation

Table 7: Estimation Results (1970-2019)

\begin{tabular}{|c|c|c|c|c|c|}
\hline \multicolumn{6}{|c|}{ Panel A: Long-Run and Short-Run Estimates } \\
\hline \multirow{4}{*}{ Cons } & \multicolumn{2}{|c|}{ Long-Run } & \multirow{4}{*}{$\Delta \operatorname{In} G P_{t}$} & \multicolumn{2}{|c|}{ Short-Run } \\
\hline & US & Canada & & US & Canada \\
\hline & $-2.036 * * *$ & -0.066 & & $0.280 * * *$ & $0.197 *$ \\
\hline & $(-5.139)$ & $(-0.213)$ & & $(3.054)$ & $(2.001)$ \\
\hline Trend & - & $\begin{array}{c}0.019 * * * \\
(4418)\end{array}$ & $\Delta \operatorname{In} G P_{t-1}$ & - & - \\
\hline \multirow[t]{2}{*}{ In $G P_{t}$} & $\begin{array}{c}2.079 * * * \\
(8.955)\end{array}$ & $\begin{array}{c}0.525 * * \\
(2.020)\end{array}$ & & & $\begin{array}{l}0.007^{* *} \\
(2383)\end{array}$ \\
\hline & & & $E C M_{t-1}$ & $\begin{array}{c}-0.134 * * * \\
(-2.976)\end{array}$ & $\begin{array}{c}- \\
0.376^{* * * *} \\
(-3.395)\end{array}$ \\
\hline \multicolumn{6}{|c|}{ Panel B: Model Diagnostics } \\
\hline & $X_{S C}^{2}$ & $X_{F F}^{2}$ & $X_{N O R M}^{2}$ & $X_{H E T}^{2}$ & \\
\hline \multirow[t]{2}{*}{ Canada } & 0.733 & 3.397 & 0.013 & 0.938 & \\
\hline & [0.392] & [0.065] & [0.993] & [0.333] & \\
\hline \multirow[t]{2}{*}{ US } & 0.560 & 0.090 & 3.378 & 0.073 & \\
\hline & [0.454] & {$[0.764]$} & [0.185] & [0.787] & \\
\hline
\end{tabular}

Notes: In Panel A, reported values are coefficients and figures in brackets are test-statistics. *** denotes statistical significance at $1 \%$ level. $* *$ indicates significance at $5 \%$ level. For Model diagnostics, figures in brackets are p-values. The dependent variable is logged stock price $\left(\right.$ In $\left.S P_{t}\right)$.The computed $F$-statistics when stock price is considered the dependent variable are: US (5.315); Canada (6.591). For US, we find conclusive evidence of cointegration at $10 \%$ significance level; For Canada, we find evidence of cointegration at $5 \%$ significance level. Plot of Cumulative Sum of Recursive Residuals and Plot of Cumulative Sum of Squares of Recursive Residuals indicates the estimated model is stable over the sample period in both countries. The results are available from the author upon request.

We also include money supply in the augmented regression model. Humpe and Macmillan (2009) notes that changes in the money supply can affect stock prices through three channels. First, an increase in the money supply results in an unanticipated rise in the inflation and future inflation uncertainty and has a negative impact on stock prices. Second, an increase in the money supply boosts economic activity, and raises stock prices. Third, according to the portfolio theory, an increase in the money supply causes investors to adjust their portfolio to include more equities, positively affecting stock prices. Thus, the effect of money supply on stock prices is an empirical question.

Another important factor affecting stock prices is interest rate. Changes in the interest rate directly affect the discount rate in the present value model and affects current and future values of cash flows (Humpe and Macmillan 2009). Theory suggests that both the short-term and longterm interest rates negatively affects stock returns. Higher interest rates increase financing 
costs, reduces future corporate profits and stock prices. Higher interest rates also cause investors adjust the portfolio and invest more in bonds, reducing stock prices (Erden, Arslan and Erdem 2005). Thus, interest rates and stock prices are expected to be negatively related.

Finally, we include exchange rates as Ratanapako and Sharma (2007) argue that exchange rates should not be ignored when studying stock prices, as money supply is useful for stabilizing exchange rates. Furthermore, movements in the exchanges reinforces the link from money supply to inflation. Exchange rate affects interest rates and influences stock prices, and is useful for investors to decide whether to invest in the stock market or the foreign exchange market.

There are at least three explanations for stock price-exchange rate nexus (Ratanapako and Sharma 2007). First, from a micro-economic perspective, an increase in exchange rate reduces profitability of firms and therefore adversely affects stock prices. Second, an appreciation of exchange rate reduces exports competitiveness and affects stock prices in an export - dominant country under a floating exchange rate. In contrast, in an import-dominant economy exchange rate appreciation reduces cost of inputs, and raises stock prices. Third, given that exchange rates affect economic activity, it might also affect stock prices. Thus, we include four control variables in our empirical analysis: money supply $\left(\operatorname{In} L M_{t}\right)$, industrial production $\left(\operatorname{In} I P_{t}\right)$, long-term interest rate $\left(I n t_{t}\right)$, and real exchange rate $\left(\operatorname{In} E X_{t}\right)$.

We can make five important observations from Table 8. First, in all four cases, the estimated coefficient of goods prices (Fisher coefficient) in the United States and Canada is more than one and statistically significant in the long-run. It is worthwhile to note that after including additional control variables, particularly for Canada, the estimated coefficient of good prices (Fisher coefficient) increases from 0.49 to 1.80 . Thus, the augmented regression model offers even stronger support for the hypothesis that stock market investment can help hedge against inflation.

Second, long-term interest rate has a statistically significant negative impact on stock prices in both countries. An increase in the long-term interest rates reduces stock prices by increasing financing cost and reducing cash flow or by causing investors to adjust their portfolio and invest more in bonds. This observation is consistent with theory and past studies by Ratanapako \& Sharma (2007) and Humpe \& Macmillan (2009).

Third, an increase in real exchange rate is positively associated with stock prices in the United States but negatively with stock prices in Canada. Furthermore, the effect is significant in the United States but not in Canada suggesting presence of heterogenous effects across two countries. Fourth, industrial production does not have a significant effect on stock prices in both countries and is consistent with findings from past studies (see, for example, Ratanapako \& Sharma 2007; Humpe \& Macmillan 2009). Fifth, three events namely 1973 Oil Embargo, 1987 stock market crash, 2008 Global Financial Crisis and Great Recession did not have a significant effect on the stock prices in both countries in the long-run. 
SAMI Stock Market Investment and Inflation

Table 8: Long-Run Estimates of the Augmented Regression Model

\begin{tabular}{|c|c|c|c|c|}
\hline & \multicolumn{2}{|c|}{ US } & \multicolumn{2}{|c|}{ Canada } \\
\hline \multirow{3}{*}{$\begin{array}{l}\text { Regressor } \\
\text { In } \mathrm{GP}_{\mathrm{t}}\end{array}$} & Coefficient & Coefficient & Coefficient & Coefficient \\
\hline & $1.169 * * *$ & $1.530 * * *$ & $1.798 * * *$ & $1.286 *$ \\
\hline & (3.893) & (3.711) & (3.112) & (1.843) \\
\hline \multirow{2}{*}{ In $\mathrm{LM}_{\mathrm{t}}$} & 0.024 & -0.115 & $-1.357^{*}$ & -1.268 \\
\hline & $(0.110)$ & $(-0.456)$ & $(-1.898)$ & $(-1.199)$ \\
\hline \multirow[t]{2}{*}{$\mathrm{Int}_{\mathrm{t}}$} & $-0.043 * * *$ & $-0.051 * * *$ & $-0.052 * * *$ & $-0.036^{*}$ \\
\hline & $(-6.862)$ & $(-6.467)$ & $(-3.095)$ & $(-1.756)$ \\
\hline \multirow[t]{2}{*}{ In $\mathrm{EX}_{\mathrm{t}}$} & $0.749 * *$ & $0.703^{*}$ & -0.512 & -0.181 \\
\hline & $(2.228)$ & (1.863) & $(-1.150)$ & $(-0.298)$ \\
\hline \multirow[t]{2}{*}{ In $\mathrm{IP}_{\mathrm{t}}$} & 0.674 & 0.137 & -0.568 & 0.067 \\
\hline & $(1.657)$ & $(0.233)$ & $(-1.029)$ & $(0.090)$ \\
\hline \multirow[t]{2}{*}{ Cons } & $-3.000 * * *$ & $-2.629 * *$ & -1.390 & -2.427 \\
\hline & $(-3.200)$ & $(-2.440)$ & $(-0.908)$ & $(-1.053)$ \\
\hline Trend & 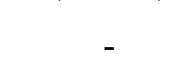 & 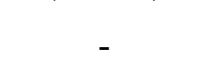 & $0.026^{*}$ & $\begin{array}{c}0.030 \\
(1420)\end{array}$ \\
\hline DUM_1973 & & -0.014 & & -0.076 \\
\hline OPEC & - & $(-0.120)$ & - & $(-0.429)$ \\
\hline DUM_1987 & & 0.136 & & 0.209 \\
\hline Crash & - & (1.211) & - & (1.160) \\
\hline DUM_2008 & - & -0.143 & - & -0.038 \\
\hline GR & - & $(-1.110)$ & 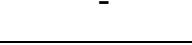 & $(-0.214)$ \\
\hline
\end{tabular}

Notes: Figures in brackets are test-statistics. $* * *$ denotes statistical significance at $1 \%$ level, ** indicates significance at $5 \%$ level and * indicates significance at $10 \%$ level. The dependent variable is logged stock price $\left(\operatorname{In} S P_{t}\right)$.

The short-run results in Table 9 indicate that good prices have consistent positive effects on stock prices across two countries. The results for the United States reveal that money supply and long-term interest rates still have significant negative influence on stock prices at 1 percent level. However, industrial production is positively and significantly related with the stock prices in Canada. The coefficient of lagged error-correction term is negative and statistically significant at 1 percent, confirming evidence of cointegration between the variables.

The model diagnostics summarized in Panel B shows that our empirical results are valid and standard classical assumptions are not violated. We find the results are insensitive to including additional control variables and possible structural breaks. Hence, the results from estimation of the augmented regression model confirms not only our earlier findings but offers even firm evidence that good prices and stock prices are strongly positively related in the short-run and long-run. In both countries, we find robust evidence that stock market investment can help hedge against inflation. 
Review of Economic Analysis 13 (2021) 339-365

Table 9: Short-Run Model and Model Diagnostics

\begin{tabular}{|c|c|c|c|c|}
\hline \multicolumn{5}{|c|}{ Panel A: Short-Run Estimates } \\
\hline & \multicolumn{2}{|c|}{ US } & \multicolumn{2}{|c|}{ Canada } \\
\hline Regressor & Coefficient & Coefficient & Coefficient & Coefficient \\
\hline$\Delta \operatorname{In} G P_{t}$ & $\begin{array}{c}0.522 * * * \\
(3.319)\end{array}$ & $\begin{array}{c}\mathbf{0 . 6 0 4} * * * \\
(3.638)\end{array}$ & $\begin{array}{c}0.730 * * * \\
(3.141)\end{array}$ & $\begin{array}{l}0.396 * \\
(1.996)\end{array}$ \\
\hline$\Delta \operatorname{In} L M_{t}$ & $-1.264 * * *$ & $-1.447 * * *$ & 0.429 & -0.390 \\
\hline$\Delta \operatorname{Int}_{t}$ & $\begin{array}{c}-0.019 * * * \\
(-3.680)\end{array}$ & $\begin{array}{c}-0.020 * * * \\
(-3.881)\end{array}$ & $\begin{array}{l}-0.001 \\
(-0.138)\end{array}$ & $\begin{array}{l}-0.011^{*} \\
(1.794)\end{array}$ \\
\hline$\Delta \operatorname{In} E X_{t}$ & $\begin{array}{l}0.335^{*} \\
(1.905)\end{array}$ & $\begin{array}{c}0.277 \\
(1.582)\end{array}$ & $\begin{array}{c}0.723 * * \\
(2.149)\end{array}$ & $\begin{array}{c}-0.056 \\
(-0.297)\end{array}$ \\
\hline$\Delta \operatorname{In} I P_{t}$ & $\begin{array}{c}0.301 \\
(1.433)\end{array}$ & $\begin{array}{c}0.054 \\
(0.226)\end{array}$ & $\begin{array}{c}1.019 * * * \\
(2.722)\end{array}$ & $\begin{array}{c}1.236 * * * \\
(2.977)\end{array}$ \\
\hline$\Delta$ Trend & 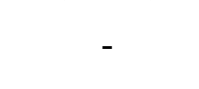 & 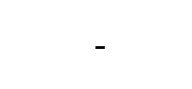 & $\begin{array}{l}0.011^{*} \\
(1.907)\end{array}$ & $\begin{array}{c}0.009 \\
(1.435)\end{array}$ \\
\hline $\begin{array}{c}\triangle D U M \_1973 \\
O P E C\end{array}$ & - & $\begin{array}{l}-0.005 \\
(-0.120\end{array}$ & - & $\begin{array}{c}-0.023 \\
(-0.441)\end{array}$ \\
\hline$\triangle D U M \_1987$ & - & $\begin{array}{c}0.054 \\
(1.269)\end{array}$ & - & $\begin{array}{c}0.064 \\
(1.231)\end{array}$ \\
\hline$\Delta D U M \_2008$ & & -0.056 & & -0.012 \\
\hline$G R$ & & $(-1.234)$ & & $(-0.219)$ \\
\hline$E C M_{t-1}$ & $\begin{array}{c}-0.447 * * * \\
(-4.708) \\
\end{array}$ & $\begin{array}{c}-0.395 * * * \\
(-4.122) \\
\end{array}$ & $\begin{array}{c}-0.406 * * * \\
(-4.127) \\
\end{array}$ & $\begin{array}{c}-0.308 * * * \\
(-3.025) \\
\end{array}$ \\
\hline \multicolumn{5}{|c|}{ Panel B: Model Diagnostics } \\
\hline$X_{s c}^{2}$ & $\begin{array}{c}3.096 \\
{[0.078]}\end{array}$ & $\begin{array}{c}2.716 \\
{[0.099]}\end{array}$ & $\begin{array}{c}0.550 \\
{[0.458]}\end{array}$ & $\begin{array}{c}0.106 \\
{[0.745]}\end{array}$ \\
\hline$X_{F F}^{2}$ & 0.425 & 0.083 & 1.875 & 3.206 \\
\hline$X_{N O R M}^{2}$ & $\begin{array}{l}{[.515]} \\
3.443\end{array}$ & $\begin{array}{c}{[0.774]} \\
2.286\end{array}$ & $\begin{array}{c}{[0.171]} \\
0.922\end{array}$ & {$[.073]$} \\
\hline & {$[0.179]$} & {$[0.319]$} & {$[0.631]$} & $2.400[0.301]$ \\
\hline$X_{H E T}^{2}$ & 1.793 & 0.846 & 0.418 & \\
\hline & {$[0.181]$} & {$[0.358]$} & {$[0.518]$} & $1.381[0.240]$ \\
\hline
\end{tabular}

Notes: In panel A, figures in brackets are t-statistics. In panel B, figures in brackets are p-values. $* * *$ denotes statistical significance at $1 \%$ level, $* *$ indicates significance at 5 $\%$ level and * indicates significance at $10 \%$ level. Plot of Cumulative Sum of Recursive Residuals and Plot of Cumulative Sum of Squares of Recursive Residuals indicates the estimated model is stable over the sample period in US and Canada. The results are available from the author upon request. In both cases, we found evidence of cointegration at 10 percent level. When three dummy variables were included, the evidence of cointegration is unclear at 10 percent. Therefore, we examine the significance of the coefficient of lagged error-correction term to confirm evidence of cointegration between the variables (see Table 9). 
SAMI Stock Market Investment and Inflation

\section{Concluding Remarks and Policy Implications}

Over the past few decades, a growing number of studies have investigated whether stock market investment can help hedge against inflation. However, bulk of studies have used stock return and inflation-resulting loss of valuable long-run information, and found mixed evidence. In contrast, an emerging strand of empirical studies has investigated whether stock market investment can help hedge against inflation by examining the long-run relationship between stock prices and goods prices. The main goal of this paper is to contribute to this emerging literature and investigate the long-run relationship between stock prices and goods prices in two important economies - the US and Canada, within a univariate unit and cointegration framework using annual data covering a large sample period (1960 to 2019).

This study employed an ARDL cointegration test and finds that there is a meaningful long-run economic relationship between goods prices and stock prices in both economies. The relationship is not only found to be positive but also statistically significant. Our findings suggest developments in the good prices significantly affected the stock market in both economies. Further estimations reveal that the long-run elasticity of stock prices with respect to good prices (Fisher coefficient) is above one for the US and Canada.

There is strong evidence that stock market investment can help hedge against inflation in the US and Canada. Stocks maintain their value relative to movements in the goods prices over the long-run, and investors should expect stock market investment in the US and Canada to shelter them from inflation. Controlling for the effects of various macroeconomic factors, we find strong evidence that stock market investment can help hedge against inflation in the US and Canada-a finding important for investors and fund managers. Future studies can extend the present study by examining the relationship between good prices and sectoral stock price indices, and whether a stable the long-run economic relationship exists between goods and stock market in developing and emerging market economies ${ }^{6}$.

\section{Endnotes}

1. Stocks represent claims to real assets, and therefore are expected to maintain their value in face of inflation.

2. For discussion of the derivation of the long-run model and theoretical literature, see: Ely and Robinson (1997), Luintel and Paudyal (2006) and Anari and Kolari (2001). The derivation of the empirical model is not presented here to conserve space.

3. We do examine the role of other macroeconomic factors in stock prices in both countries as a robustness check in section 4.5. An in-depth analysis of all the factors affecting stock prices is beyond the scope and we leave this as an area for future research.

4. We also experimented with testing for nonlinear impact of goods prices on the stock prices. However, the results reveal no significant evidence of nonlinear impact. The results are available from the author upon request.

5. We thank the reviewers for this suggestion. Given that industrial production for Canada was available from 1961 onwards, the sample period for the estimation is 1961 to 2019. 
Industrial production data and money supply are taken from OECD database, long-term interest is measure by 10 - year government bond yield from Federal Reserve Bank of St. Louis (2021), while the exchange rate is measured as real exchange rate and taken from Darvas (2012) database. Chu (2016) discusses the issue of money and prices in Canada.

6. The data that support the findings of this study are available from the corresponding author upon request.

\section{References}

Alagidede, P., \& Panagiotidis , T. (2012). Stock returns and inflation: Evidence from quantile regressions. Economics Letters, 117(1), 283-286.

Alagidede, P., \& Panagiotidis, T. (2010). Can common stocks provide a hedge against inflation? Evidence from African countries. Review of Financial Economics, 19(3), 91-100.

Al-Khazali, O. M., \& Pyun, C. S. (2004). Stock prices and inflation: New evidence from the Pacific-Basin countries. Review of Quantitative Finance and Accounting, 22(2), 123-140.

Al-Nassar, N. S., \& Bhatti, R. H. (2018). Are common stocks a hedge against inflation in emerging markets? Journal of Economics and Finance, 1-35.

Anari, A., \& Kolari, J. (2001). Stock prices and inflation. Journal of Financial Research, 24(4), 587-602.

Bhuiyan, E. M., \& Chowdhury, M. (2020). Macroeconomic variables and stock market indices: Asymmetric dynamics in the US and Canada. The Quarterly Review of Economics and Finance, 77, 62-74.

Bodie, Z. (1976). Common Stocks as a Hedge Against Inflation. The Journal of Finance, 31(2), 459-470.

Brown, R. L., Durbin, J., \& Evans, J. M. (1975). Techniques for testing the constancy of regression relationships over time. Journal of the Royal Statistical Society. Series B (Methodological), 149-192.

Chu, K. H. (2016). Friedman Meets Hayek on Money and Prices in Canada. Review of Economic Analysis, 8(1), 69-96.

Darvas, Z. (2012). Real effective exchange rates for 178 countries: a new database. Bruegel Working Paper 2012/06. https://www.bruegel.org/publications/datasets/real-effectiveexchange-rates-for-178-countries-a-new-database/ (accessed on 6 May 2021).

Dickey, D. A., \& Fuller, W. A. (1979). Distribution of the Estimators for Autoregressive Time Series With a Unit Root. Journal of the American Statistical Association, 74(366), 427-431.

Dickey, D. A., \& Fuller, W. A. (1981). Likelihood Ratio Statistics for Autoregressive Time Series with a Unit Root. Econometrica, 49(4), 1057-1072.

Ely, D. P., \& Robinson, K. J. (1997). Are stocks a hedge against inflation? International evidence using a long-run approach. Journal of International Money and Finance, 16(1), 141-167. 
Engle, R. F., \& Granger, C. W. (1987). Co-integration and Error Correction: Representation, Estimation, and Testing. Econometrica, 55(2), 251-276.

Erdem, C., Arslan, C. K., \& Sema Erdem, M. (2005). Effects of macroeconomic variables on Istanbul stock exchange indexes. Applied Financial Economics, 15(14), 987-994.

Federal Reserve Bank of St. Louis. (2020). FRED Economic Data. https://fred.stlouisfed.org/. (accessed on December 10 2020).

Federal Reserve Bank of St. Louis. (2021). FRED Economic Data. https://fred.stlouisfed.org/. (accessed on May 6 2021).

Fisher, I. (1930). The Theory of Interest: Macmillan, New York.

Gan, C., Lee, M., Yong, H. H. A., \& Zhang, J. (2006). Macroeconomic variables and stock market interactions: New Zealand evidence. Investment Management and Financial Innovations, 3(4), 89-101.

Gregoriou, A., \& Kontonikas, A. (2010). The long-run relationship between stock prices and goods prices: New evidence from panel cointegration. Journal of International Financial Markets, Institutions and Money, 20(2), 166-176.

Gultekin, N. B. (1983). Stock Market Returns and Inflation: Evidence from Other Countries. The Journal of Finance, 38(1), 49-65.

Hassan, K., Hoque, A., \& Rao, A. (2015). Revisiting the Link Between Stock Prices and Goods Prices in OECD Countries. Australian Economic Papers, 54(3), 135-150.

Haug, A. A. (2002). Temporal Aggregation and the Power of Cointegration Tests: a Monte Carlo Study*. Oxford Bulletin of Economics and Statistics, 64(4), 399-412.

Humpe, A., \& Macmillan, P. (2009). Can macroeconomic variables explain long-term stock market movements? A comparison of the US and Japan. Applied Financial Economics, 19(2), 111-119.

Hussain, S. M., \& Omrane, W. B. (2021). The effect of US macroeconomic news announcements on the Canadian stock market: Evidence using high-frequency data. Finance Research Letters, 38, 101450.

Khil, J., \& Lee, B. S. (2000). Are common stocks a good hedge against inflation? Evidence from the Pacific-rim countries. Pacific Basin Finance Journal, 8(3-4), 457-482.

Kim , S., \& In , F. (2005). The relationship between stock returns and inflation: New evidence from wavelet analysis. Journal of Empirical Finance, 12(3), 435-444.

Kim, J. H., \& Ryoo, H. H. (2011). Common stocks as a hedge against inflation: Evidence from century-long US data. Economics Letters, 113(2), 168-171.

Lee, J., \& Strazicich, M. C. (2003). Minimum Lagrange multiplier unit root test with two structural breaks. Review of Economics and Statistics, 85(4), 1082-1089.

Li, Y. D., İşcan, T. B., \& Xu, K. (2010). The impact of monetary policy shocks on stock prices: Evidence from Canada and the United States. Journal of International Money and Finance, 29(5), 876-896. 
Luintel, K. B., \& Paudyal, K. (2006). Are common stocks a hedge against inflation? Journal of Financial Research, 29(1), 1-19.

Lumsdaine, R. L., \& Papell, D. H. (1997). Multiple trend breaks and the unit-root hypothesis. Review of Economics and Statistics, 79(2), 212-218.

Madadpour, S., \& Asgari, M. (2019). The puzzling relationship between stocks return and inflation: a review article. International Review of Economics, 66(2), 115-145.

Narayan , P. K. (2005). The saving and investment nexus for China: evidence from cointegration tests. Applied Economics, 37(17), 1979-1990.

Narayan, P. K., \& Popp, S. (2010). A new unit root test with two structural breaks in level and slope at unknown time. Journal of Applied Statistics, 37(9), 1425-1438.

Narayan, P. K., \& Popp, S. (2013). Size and power properties of structural break unit root tests. Applied Economics, 45(6), 721-728.

OECD (2021), "Finance", Main Economic Indicators (database), https://doi.org/10.1787/data00043-en (accessed on 21 January 2021).

Omay , T., Yuksel, A., \& Yuksel, A. (2015). An empirical examination of the generalized Fisher effect using cross-sectional correlation robust tests for panel cointegration. Journal of International Financial Markets, Institutions and Money, 35, 18-29.

Omay, T., Hasanov, M., Yuksel, A., \& Yuksel, A. (2016). A Note on the Examination of the Fisher Hypothesis by Using Panel Co-Integration Tests with Break. Journal for Economic Forecasting, XIX(2), 13-26.

Perron, P. (1989). The Great Crash, the Oil Price Shock, and the Unit Root Hypothesis. Econometrica, 57(6), 1361-1401.

Pesaran , H., \& Shin, Y. (1999). An Autoregressive Distributed Lag Modelling Approach to Cointegration Analysis. In In Econometrics and Economic Theory in the 20th Century: the Ragnar Frisch Centennial Symposium: Cambridge: Cambridge University Press.

Pesaran, M. H., Shin, Y., \& Smith, R. J. (2001). Bounds testing approaches to the analysis of level relationships. Journal of Applied Econometrics, 16(3), 289-326.

Phillips, P. C., \& Perron, P. (1988). Testing for a unit root in time series regression. Biometrika, 75(2), 335-346.

Rahman, M. (2008). Influences of money supply and oil price on US stock market. North American Journal of Finance and Banking Research, 2(2), 1-12.

Ratanapakorn, O., \& Sharma, S. C. (2007). Dynamic analysis between the US stock returns and the macroeconomic variables. Applied Financial Economics, 17(5), 369-377.

Rushdi , M., Kim, J. H., \& Silvapulle, P. (2012). ARDL bounds tests and robust inference for the long run relationship between real stock returns and inflation in Australia. Economic Modelling, 29(3), 535-543.

Sen, A. (2003). On Unit-Root Tests When the Alternative Is a Trend-Break Stationary Process. Journal of Business \& Economic Statistics, 21(1), 174-184. 
Spyrou, S. I. (2001). Stock returns and inflation: Evidence from an emerging market. Applied Economics Letters, 8(7), 447-450.

Spyrou, S. I. (2004). Are stocks a good hedge against inflation? Evidence from emerging markets. Applied Economics, 36(1), 41-48.

Wong, W. K., Khan, H., \& Du, J. (2006). Do money and interest rates matter for stock prices? An econometric study of Singapore and USA. The Singapore Economic Review, 51(01), 3151.

World Bank. (2021). World Development Indicators. http://data.worldbank.org/datacatalog/world-development-indicators (accessed on 20 January 2021).

Zivot, E., \& Andrews, D. W. K. (1992). Further Evidence on the Great Crash, the Oil-Price Shock, and the Unit-Root Hypothesis. Journal of Business \& Economic Statistics, 10(3), 251-270. 